\title{
THE SECOND OFFICER IN THE GOVERNMENT
}

\section{By William H. Fleming}

The federal constitution provides for the election of the first two officers of the government, and the several state constitutions make like provision for filling the highest two offices therein. The second officer in each state is designated as a lieutenant-governor except in. Arkansas, Florida, Georgia, Maine, Maryland, New Hampshire, New Jersey, Oregon, Tennessee, Utah, West Virginia, and Wyoming. The national constitution makes provision for supplying such second officer when either or both of the first two places become vacant, and like provision is made in probably all of the states for filling such offices when necessary. The first constitution of Iowa made the secretary of state the second officer, with the president of the Senate and the speaker of the House of Representatives in succession to be such second officer in case of vacancy. The present constitution of Iowa, like that of Ohio, makes only partial provision for supplying the second officer when such a one is needed, as will be seen further on.

THE LIEUTENANT-GOVERNSHIP IN IOWA

Under the first constitution of Iowa, among the occasions when the second officer of the government could act as governor was one where the absence of the governor from the state caused such a vacancy. There is a tradition that some of the several secretaries of state would, immediately upon the governor leaving the state for ever so short a time, step into the executive office and proceed to officiate therein.

When the present constitution was under consideration in the convention of 1857 , the then governor of the state, James W. Grimes, was undoubtedly much consulted in respect to changes in the fundamental law. It is not improbable that Governor Grimes, in view of his experience in respect to the executive office being occasionally invaded for a short time-perhaps a day or two-by another officer who was conveniently located for so doing, favored the creation of the office of lieutenant-governor, the incumbent of which would ordinarily be resident at some place 
more or less remote from the seat of government, and would not expect to act as governor unless there was something of a real vacancy in the executive office. The state of Ohio, only a few years previously, had established that office, and that constitution would seem to have been something of a guide for our constitution-makers. The provisions of that constitution respecting the lieutenant-governorship, were copied literally into our new fundamental law, of which more will appear presently. With reference to the possible vacancy in the governorship, our present constitution makes the death, impeachment, resignation, removal from office, or other disability, absence from the state not being one, the only occasions when the duties of the governorship could be entered upon by other than the first magistrate. Consequently the only instances when the second officer of the government has taken upon himself the duties of the chief magistrate were when the governor resigned the first office, as did Governors Kirkwood and Cummins, respectively in 1877 and 1908.

In 1870 Madison M. Walden, the seventh lieutenant-governor, resigned that office, he having been nominated for representative in Congress. When the governor, Samuel Merrill, received that resignation, he was under the impression that the president pro tem of the Senate then became the second officer in the state, and as such, should an emergency require it, would enter upon the discharge of the duties of chief executive, with the speaker coming next in the succession. But in the summer of 1871 the Governor received from Henry C. Bulis, the president pro tem of the Senate, his resignation as senator, he having been nominated for lieutenant-governor. As his term of office as senator would not expire until after the lapse of two years more, his resignation permitted the choosing of his successor at the approaching election. This resignation caused the Governor much perplexity. He was repeatedly urged to appoint a lieutenant-governor, which he hesitated to do for some time; but finally, while doubting his power in the premises, he appointed Senator Bulis lieutenantgovernor. On his accepting the same, he became the eighth lieutenant-governor of Iowa. In his biennial message to the General Assembly, convened soon afterward, the Governor recounted the facts above set forth and commented thereon as follows: 
Thus both of the offices, whose incumbents could perform the duties of the governor in case of a vacancy in that office, were themselves vacant, leaving no one qualified by law to succeed to the governorship. $\Lambda$ fter examining the constitution and the law bearing upon the question, I determined to act upon the authority conferred by Section 10, Article IV of the constitution, and Section 664 of the Revision, and appointed Hon. Henry C. Bulis of Winneshiek County, lieutenant-governor of the state. I am aware that, in thus naming a presiding officer for the Senate I ventured upon delicate ground, and went perhaps to the verge of the constitutional power of the executive; but I trust that the emergency which alone could have induced me to act will also be my justification. 'I'he examination $I$ made at the time the matter of this appointment was before me, led me to observe, more closely than I had done before, the language of the constitution upon the subject; and $I$ found that under a strict construction of that instrument, a lieutenant-governor only can succeed to the governorship upon the death, resignation, or impeachment of the governor. The provision for the succession of the president pro tcmpore of the Senate, and of the speaker of the House of Representatives, applies only to cases where the lieutenant-governor, zohile exercising the duties of the office of governor, shall die, resign, or be impeached. The intent of the constitution is probably that these officers shall succeed in the order named, whenever a vacancy shall happen in the executive office, but the literal fact is as I have stated. I suggest that if the General Assembly shall deem it within the range of its powers, an act be passed supplementing constitutional provisions respecting tre succession to the gubernatorial office, and especially providing for any emergency similar to the one above referred to.

The sections of the present Iowa constitution, adopted in 1857, having reference to the matter under consideration are 17, 18, and 19, of Article IV, and are as follows:

Sec. 17. In case of the death, impeachment, resignation, removal from office, or other disability of the governor, the powers and duties of the office for the residue of the term, or until he shall be acquitted, or the disability removed, shall devolve upon the lieutenant-governor.

Sec. 18. The lieutenant-governor shall be president of the Senate, but shall only vote when the Senate is equally divided; and in case of his absence, or impeachment, or when he shall exercise the office of govcrnor, the Senate shall choose a president pro tempore.

Sec. 19. If the lieutenant-governor, while acting as governor, shall be impeached, displaced, resign, or die, or otherwise become incapable of performing the duties of the office, the president pro tempore of the Senate shall act as governor until the vacancy is filled, or the disability removed; and if the president of the Senate for any of the above causes, shall be rendered incepable of performing the duties pertaining to the office of governor, the same shall devolve upon the speaker of the House of Representatives. 
The sections of the constitution quoted were literally copied from sections 16,17 , and 18 , of Article III of the constitution of Ohio, adopted in 1851. No interpretation of these articles has been given judicially in this state, but it happens that they have been definitely interpreted by the Supreme Court of Ohio.

The case that elicited the judgment of that court was that of the State ex rel Trauger vs. Nash, Governor, found in 36th Ohio State Reports, Vol. LXVI, page 612. In May, 1902, Carl L. Lippert, the lieutenant-governor, having been elected to a judicial office in the city of Cincinnati, resigned his state office. The governor was then urged to make an appointment to fill the vacancy. This he refused, or rather declined, to do. Thereupon a petition in mandamus was filed with the permission of the Supreme Court, requiring the governor to make the appointment in question. Section 27, of Article II, of the constitution of the state thus provides:

The election and appointment of all officers, and the filling of all vacancies, not otherwise provided by this constitution or that of the United States, shall be made in such manner as shall be directed by law.

The court ruled that the governor could be required by mandamus to make the appointment as a purely ministerial duty, the law of the state requiring him to fill vacancies, and there being no other provision in the constitution for filling a vacancy in the lieutenant-governorship, such vacancy must be filled by the governor as provided in the statutes.

In this state the constitution, Article IV, Section 10, authorizes the governor to fill all vacancies when no mode is provided therefor by the constitution and laws. Is not that Ohio ruling applicable to the situation here of $1870-71$, or even more so, if there is any difference? Our fundamental law makes it the duty of the governor to make appointments in all cases where the law does not otherwise provide for filling vacancies in office, that matter not being left for the legislature to act upon. Under the ruling cited, had not Governor Merrill the power, and may it not have been his duty, to appoint a lieutenant-governor upon receiving word of Mr. Walden's resignation? Such person would then have been the second officer in the state government as Lieutenant-Governor Bulis became when he was selected for the position. The governor of Ohio, when advised by the Supreme 
Court as to his authority and duty in the premises, duly appointed a lieutenant-governor. A few years later LieutenantGovernor Atlee Pomerene resigned that office, he having been elected a senator of the United States, whereupon Governor Harmon selected his successor. Thus two lieutenant-governors of Ohio have been appointed by the governor during the present century under a constitutional provision identical with that found in our fundamental law.

It would have been well had the legislature of this state followed up the suggestion of Governor Merrill and made suitable provision for meeting such emergency. Our legislature was then adopting a new code, and it was an opportune time for filling up the legislative hiatus. It would have been well too, had our constitution a provision requiring the legislature to make some such enactment as that cited above in the federal constitution. Why may not the revision of our laws, now pending, do something towards filling up that vacuum in the statutes?

Under the interpretation put upon the constitution of Ohio as herein cited, can any officer succed to the governorship in Iowa in case of a vacancy therein, other than a lientenant-governor, either elected or appointed, the only instances when the temporary president of the Senate and the speaker are in the succession being when both the first offices are vacant?

In 1877 the governorship of this state became vacant upon Governor Kirkwood resigning the office in order that he might enter on the discharge of his duties as senator of the United States. Thereupon Joshua G. Newbold, the tenth lieutenantgovernor, entered on the discharge of the duties of the executive. At that time Henry W. Rothert, a senator from Lee County, was president pro tem, and thus the second officer in the state with Speaker Gear coming next. Senator Rothert suggested to Governor Newbold that the latter might appoint him lieutenantgovernor, as Bulis had been appointed. This Governor Newbold felt he could not do because the lieutenant-governorship was not vacant. It was the governship that was vacant, the lieutenantgovernor performing executive duties because of that vacancy. Could there be two lieutenant-governors in the state? Senator Rothert continued, however, to discharge the duties of president pro tem, notwitlistanding his term as senator had expired, and 
he presided in the joint convention that canvassed the votes for governor and lieutenant-governor, and in the inauguration of Governor Gear and Lieutenant-Governor Campbell. At one time during the session when Senator Rothert was yet acting as president pro tem, Senator Lafayette Young moved that the Senate proceed to choose a president pro tem, which was negatived. This non-action of the Senate may be looked upon as that body's approval of the course of the acting president pro tem.

This situation now suggests another question. Suppose that from any cause Governor Newbold had ceased to be the chief executive, could the acting president pro tem have assumed the duties of governor when in reality he was no longer such president pro tem? It would be well if the Senate, in choosing a president pro tem at the close of a session, were to elect for the position one who would be a senator in the next gubernatorial term. This was looked after in early times, as was done when Senator Bulis was put in the chair as its temporary president.

In 1908 the governship again became vacant, this time on Governor Cummins resigning in order to proceed to the performance of his duties as senator of the United States, to which position he had been elected. Thereupon Warren Garst, the twentieth lieutenant-governor, entered on the performance of executive duties. Then James Albert Smith of Osage was president pro tem, Speaker Nathan E. Kendall coming next in succession. Senator Smith was then in the last year of his second term in the Senate, and had just been elected for the third term. He presided at the joint convention which canvassed the votes for governor and lieutenant-governor and at the inauguration of Beryl F. Carroll as governor, and George W. Clarke as lieutenant-governor.

\section{WHEN THE VICE-PRESIDENCY BECOMES VACANT}

Congress at an early day acted on the authority conferred by paragraph (5) of section 1 of Article II of the constitution to "provide for the case of removal, death, resignation, or other disability both of the president and the vice-president, declaring what officer shall then act as president," such officer to act accordingly until the disability be removed, or a president elected. The first act on that subject provided that the president pro tem 
of the Senate and the speaker of the House of Representatives should in succession be such officer.

The first happening under this rule was when George Clinton, the fourth vice-president, died in the year 1812. Then William H. Crawford of Georgia was president pro tem, and thus the second officer in the government, Speaker Henry Clay being next in succession. It is an interesting fact that this was the nearest cither of these statesmen got to the presidency, although both were warmly supported by their political friends for the first office.

In 1813 Elbridge Gerry, the fifth vice-president, took the oath of office at his home at Cambridge, Massachusetts, on March 4. When the first session of the Thirteenth Congress began he went to the seat of government and assumed his duties, but during his first session as presiding officer of the Senate he gave reasons for not vacating the chair so as to allow of the choice of a president pro tem, holding that it was his duty to preside in the Senate, but before that session closed he yielded to the desire to have the Senate choose its presiding officer, and he retired from the session, whereupon John Gaillard of South Carolina was called to the chair. In November following the vice-president died at Washington, when Senator Gaillard was again made president pro tem, as he was again and again chosen until his death in 1826. In 1814 Henry Clay being yet speaker, was for a short time the third officer in the government, until appointed to negotiate a treaty of peace with Great Britain, when Langdon Cheves of South Carolina was such third officer until. Mr. Clay's return to the speakership. Mr. Clay then held the position for the remainder of that presidential term.

In December, 1832, John C. Calhoun, the seventh vice-president, resigned on his election to the Senate from his state, and Hugh Lawson White of Tennessee was president pro tem, holding the position until Martin Van Buren, the eighth vice-president, was in March, 1833, installed in that office. As the president was then Andrew Jackson of Tennessee, it thus happened that both the first and second officers of the government were for a short time from one state, Tennessee. Andrew Stevenson of Virginia was then speaker of the House. 
In 1852 William Rufus King of Alabama was elected the thirteenth vice-president. His health, however, was so much impaired that it was deemed advisable for him to go to the Island of Cuba for possible improvement. But in 1853 it was decided to permit him to take the oath of office there, and Congress authorized the American consul at Havana to administer such oath. This was accordingly done on March 4, 1853. Returning home, he died in Alabama April 18, 1853. He thus never presided as vice-president, although he had repeatedly been president pro tem. David R. Atchison of Missouri then became president pro tem, holding that position until December, 1854. Then Lewis Cass of Michigan was president pro tem for one day. On December 5, 1854, Jesse D. Bright of Indiana was elected to the chair, which position he held, except for two days when Charles E. Stuart of Michigan held the place, until on January 6, 1857, when James M. Mason of Virginia was chosen president pro tem, and he retained the position until the fourteenth vice-president, John C. Breckinridge, entered upon his duties in that office. I.inn Boyd of Kentucky was speaker of the House in 1853-55, when he was succeeded by Nathaniel Banks of Massachusetts as such third officer of the government until 1857 .

When Henry Wilson, the eighteenth vice-president, died, Thomas W. Ferry of Michigan was made president pro tem of the Senate. At that time there was some discussion regarding the propriety of having a president of the Senate, who held his position at the pleasure of that body, being called upon to discharge executive functions, but nothing was done about the matter at that time. Michael C. Kerr of Indiana was then speaker of the House, but he died in 1876 when Samuel J. Randall of Pennsylvania succeeded him, and remained the third officer of the government until the close of the Grant administration.

When Thomas A. Hendricks, the twenty-first vice-president, died, President Cleveland, believing it due the memory of his colleague on the presidential ticket of the year before, determined to attend the funeral of the departed statesman. This apparent determination of the President somewhat alarmed his political friends. They pointed out the possible dangers of the proposed trip. The assassination of President Garfield was then a recent event. But the President seemed so determined to make the jour- 
ney, and his political friends failing to shake his determination, it was suggested to Senator George F. Edmunds, Republican leader in the Senate, that he call upon the President and present to him his views of the inadvisability of the proposed trip and of its possible consequences. The Senator made the desired call upon the nation's chief. What representations the Senator made at the White House have been differently stated. The Vice-President had not left the Senate chamber so as to allow the body to elect a president pro tem. The fact that there was then no officer who could take the place of the President was one of the representations made. Another was that when the Senate should next meet, a Republican would be put in the chair of that body, and thus, should the first office become vacant, power might return to the Republican party. Both situations were then existent or in prospect. At all events, the President remained at Washington.

When Congress met Senator John Sherman of Ohio was chosen the president of the Senate, thus becoming the second officer in the government, and that was the nearest the distinguished Ohioan got to the presidency, as a candidate for which he had at different times strong support. John G. Carlisle of Kentucky was then made speaker of the House and was thus the third officer in the government.

At that session Congress provided another mode of filling the highest two offices in the government should they both become vacant. That is the law regarding the succession now on the statute books of the nation. Under that law the secretary of state may become the second officer in the government, the secretary of the treasury coming next. Other cabinet officers are arranged in order for filling vacancies in the succession. Under that enactment Secretary Bayard of Delaware succeded Senator Sherman as second officer and Daniel Manning and other cabinet officers following.

When Garret A. Hobart, the twenty-fourth vice-president, died in 1899, John Hay of Ohio was secretary of state, and Lyman J. Gage of Illinois, secretary of the treasury.

When James S. Sherman, the twenty-seventh vice-president, died, Philander C. Knox of Pennsylvania was secretary of state, and Franklin McVeagh of Illinois, at the head of the treasury. 
After the enactment of the new law as to the succession, the Senate took action towards making the president pro tem of that body a permanent officer. Succeeding Senator Sherman was John J. Ingalls of Kansas who held the place until 1891. Charles F. Manderson of Nebraska followed him for two years. Then came Isham G. Harris of Tennessee in the Fifty-third Congress, 1893-95. Then William P. Frye of Maine was president pro tem until 1911, or sixteen years. Augustus O. Bacon of Georgia presided in 1912-13, after which James P. Clarke of Arkansas held the place in 1913-15, and he was followed by Williard Saulsbury of Delaware in 1915-19. In 1919 Albert B. Cummins of Iowa was elected president pro tem, and he yet holds that position.

\section{WHEN DEATH REMOVED THE PRESIDENT}

Another situation confronted the nation when, on April 4, 1841, William Henry Harrison, ninth president of the United States, died. Thereupon John Tyler of Virginia, the tenth vice-president, entered upon the discharge of the duties of the presidency. He had not left the Senate before the close of the special session, hence there was then no president pro tem. But the Twentyseventh Congress had been summoned by President Harrison to meet on May 31 following.

On that day Samuel L. Southard of New Jersey was chosen temporary president, in which position he continued until he resigned in 1842, and Willie P. Mangum of North Carolina was elected on May 31, 1842, and filled the position until George M. Dallas, the eleventh vice-president, entered upon the duties of that office in 1845 .

An appalling accident that happened on February 28, 1814, came near making the presidency vacant. On that day a large assemblage of notables gathered on the war steamer Princeton to enjoy a trip on the Potomac in the new vessel, the first American war steamer, and also to witness the discharge of a new piece of ordnance, a wrought iron cannon called the "Peacemaker." After the gun had been discharged a couple of times an attempt was made to have a third discharge, when the gun exploded, killing six persons, including two members of the cabinet, and wounding several others. President Tyler was one of the fortunate many that escaped, but had he fallen, as did two of his cabinet, Mr. 
Mangum would have been the first man in the government. In 1841 John White of Kentucky was the speaker and hence the third officer in the government. He was succeeded two years later by John W. Jones of Virginia.

Among the slain on the Princeton was Colonel Gardiner. Before retiring from the executive office, the President became the husband of Miss Julia Gardiner, Colonel Gardiner's daughter. This was the first time when the head of the nation was married while in office. One of the offspring of that marriage was Lyon Gardiner Tyler, a man who has risen to eminence as an educator, becoming president of William and Mary College, the second oldest seat of learning in the United States. He held that position for twenty or more years, and is now its president emeritus.

When President Taylor died, July 9, 1850, Millard Fillmore, the twelfth vice-president, entered upon the presidency, and William R. King of Alabama was president pro tem and retained that position until he resigned on December 20, 1852, when David R. Atchison of Missouri was made his suceessor. Howell Cobb. of Georgia was speaker of the House, and was thus the third officer in the government until 1851, when he was succeeded by Linn Boyd of Kentucky.

When President Lincoln was assassinated and Andrew Johnson of Tennessee, the sixteenth vice-president, was sworn into the presidency, Lafayette S. Foster of Connecticut was president pro tem, and continued to hold that position until his retirement from the Senate in 1867. Then Benjamin F. Wade of Ohio was elected to the chair, and was thus the second officer in the government until March 4, 1869, when Schuyler Colfax of Indiana, the seventeenth vice-president, succeeded to the cliair of the Senate, coming there from the House of Representatives, where he had been the speaker for six years.

When President Garfield died, September 19, 1881, and the twentieth vice-president, Chester A. Arthur, succeeded to the presidency, he called a special meeting of the Senate in order that a president pro tem should be elected by that body, and thus become the second officer in the government. 'That body on October 13 chose Senator David Davis of Illinois to preside. The Senate happened to be divided equally between the two leading 
political parties, and there were two that were known as "Independents." They were Senators Davis and Mahone, the latter of Virginia. The immense difference in the physical proportions of these two men was utilized by Thomas Nast, a noted cartoonist of the time, in the production of a pictorial representation of the situation in the Senate. The leading parties were seen opposite each other, with the massive figure of the president pro tem presiding in the body, and the diminutive senator from Virginia standing on the vast shoulders of the other Independent.

When Senator Davis retired from the Senate Senator George F. Edmunds of Vermont was chosen to the chair, and held the position until the twenty-first vice-president, Thomas A. Hendricks, entered upon the duties of that office.

Joseph W. Keifer of Ohio was speaker in 1881-83, and John G. Carlisle of Kentucky was third officer in the government during the Arthur administration.

When President McKinley died in 1901 John Hay was secretary of state, and was thus the second officer in the government until Charles W. Fairbanks of Indiana became in 1905 the twenty-sixth vice-president. Lyman J. Gage of Illinois was secretary of the treasury, until he was succeeded by Leslie M. Shaw of Iowa, who was thus the third officer in the government until 1905 .

More Mormon Troubles.-The Evening Gazette contains the following: "It seems that there are, in Illinois, scattered bands of Mormons, some of which come in contact with their neighbors and occasion much difficulty. We have heard from the neighborhood of Shelby county, that about a week since a difference laving arisen between the Mormons and old residents, the former applied to the Governor for aid. The Governor ordered out several companies, who went to the scene of difficulty, but discovering that they were likely to be overmatched, returned without effecting their object."-Missouri Republican, St. Louis, June 15, 1839. (In the newspaper collection of the Historical Department of Iowa.) 
Copyright of Annals of Iowa is the property of State of Iowa, by \& through the State Historical Society of Iowa and its content may not be copied or emailed to multiple sites or posted to a listserv without the copyright holder's express written permission. However, users may print, download, or email articles for individual use. 